\title{
Primjena Testa izvedbe izvršnih funkcija (EFPT) nakon operacije meningeoma
}

Matea Ćelić

1 Andreja Bartolac

1 Zdravstveno veleučilište, Mlinarska cesta 38, 10000 Zagreb u praksi, Test izvedbe izvršnih funkcija potencijalno je vrlo korisna procjena stupnja neovisnosti u aktivnostima dnevnog života. U radu su predložena rješenja navedenih metodoloških izazova u primjeni testa.

\section{Sažetak}

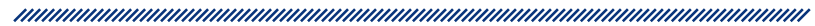

Izvršne funkcije integrirajući su sustav međusobno povezanih središnjih neuralnih procesa koji reguliraju kognitivne funkcije višeg reda te omogućuju razumijevanje ljudskog ponašanja. Oštećenje izvršnih funkcija očituje se teškoćama u samostalnom i svrhovitom obavljanju svakodnevnih aktivnosti. Cilj je ovog rada analizirati okupacijsku izvedbu osobe s teškoćama izvršnih funkcija primjenom procjene koja se ne usmjerava na izolirane značajke izvršnih funkcija, već na njihovu integraciju u kontekstu zadatka koji se izvodi. U skladu s okupacijskom paradigmom povezanosti okupacija i zdravlja, primijenjen je Test izvedbe izvršnih funkcija (Executive Function Performance Test; EFPT) i predočen kroz prikaz slučaja ženske osobe nakon operacije frontalnog meningeoma. Premda test zadovoljava psihometrijske karakteristike, neprilagođenost hrvatskom kontekstu te opisi zadataka koji dozvoljavaju samo jedan način izvedbe njegovi su glavni uočeni nedostaci. Također, standardizirani sustav navođenja predviđen u testu ne mora odražavati i stvarnu potrebnu razinu pomoći, budući da testni pribor nije sortiran u skladu s realnim kontekstom. Unatoč tome, s gledišta okupacijski orijentirane rehabilitacije i nedostatka ovakvih instrumenata
Ključne riječi: izvršne funkcije, okupacijska procjena, prikaz slučaja

Datum primitka: 06.07.2017.

Datum prihvaćanja: 15.11.2017.

DOI: $10.24141 / 1 / 3 / 2 / 2$

Adresa za dopisivanje:

Andreja Bartolac

Zdravstveno veleučilište

Mlinarska cesta 38, 10000 Zagreb

Tel.: +385 914595992

E-pošta: andreja.bartolac@zvu.hr 


\section{Uvod}

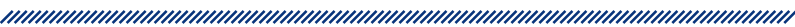

Izvršne funkcije odnose se na kognitivne funkcije višeg reda koje obuhvaćaju evolucijski odabrane prilagodbe koje pomažu pojedincu pri organizaciji vlastitog ponašanja (samoregulaciji) u kontekstu vremena i socijalnih odnosa ${ }^{1}$. Riječ je o integriranim kognitivnim procesima koji određuju cilju usmjerena i svrhovita ponašanja, a nadređeni su pri urednom izvršavanju svakodnevnih životnih aktivnosti, što uključuje mogućnost oblikovanja ciljeva, započinjanje i završavanje zadatka, predviđanje posljedica djelovanja, planiranje $i$ organiziranje ponašanja u skladu s prostornim, vremenskim, tematskim ili logičkim slijedom, kao i praćenje i prilagodbu ponašanja u skladu sodređenim zadatkom ili kontekstom². Ove integrirane funkcije uključuju i kognitivne i bihevioralne sastavnice potrebne za učinkovito, cilju usmjereno ponašanje i kontrolu resursa pažnje, koji čine osnovu samostalnosti u svakodnevnim aktivnostima. Zoltan ${ }^{3}$ navodi kako su to samoregulirajuće i kontrolne funkcije koje usmjeravaju i organiziraju ponašanje, a specifične sastavnice uključuju procese planiranja, započinjanja, održavanja i završavanja aktivnosti, anticipaciju cilja, sposobnost inhibicije, evaluaciju odgovora, vremensku organizaciju ponašanja te kognitivnu fleksibilnost ${ }^{4,5,6,7}$. S obzirom na to da su navedene sposobnosti nužne za izvedbu svakodnevnih aktivnosti pojedinca, možemo reći kako izvršne funkcije obuhvaćaju sposobnosti koje osobi omogućuju uspješno i svrhovito ponašanje ${ }^{8}$.

Istraživanja upućuju na povezanost izvršnih funkcija s prefrontalnim korteksom ${ }^{9,10,11}$ čiji je razvoj obilježen nizom progresivnih i regresivnih procesa, a koji se funkcionalno smatra ključnim za neke od najvažnijih vidova svakodnevnoga ljudskog funkcioniranja. Prema Shalli$\mathrm{ce}^{12}$, prefrontalni korteks integrira, formulira, izvršava, upravlja, modificira i prosuđuje sve aktivnosti živčanog sustava. Međutim, izvršne funkcije nisu lokalizirane samo na čeonom području (orbitofrontalni korteks), već su povezane is aktivacijom drugih dijelova mozga, kao što su parijetalni i temporalni korteks, hipokampus, asocijacijska i supkortikalna područja, uključujući i limbička polja ${ }^{13}$. U literaturi se spominju dominantne funkcije pojedinih područja frontalnog režnja i prefrontalne kore. Općenito, prednji dijelovi frontalnog režnja uključeni su u aspekte samoregulacije, npr. inhibicija i svijest o sebi, dok su stražnji dijelovi uključeni u procese rasuđivanja ${ }^{14}$. Preciznije, motivacija i odabir akcije u odnosu na ciljeve pripisuje se medijalnoj prefrontalnoj kori $^{15}$, donošenje odluka ${ }^{16} \mathrm{i}$ inhibicijska kontrola ponašanja ${ }^{17}$ orbitofrontalnom korteksu, dok je dorzolateralni dio povezan $\mathrm{s}$ planiranjem ${ }^{18}$, radnim pamćenjem ${ }^{19} \mathrm{i}$ kognitivnom fleksibilnošću ${ }^{20}$.

Oštećenje izvršnih funkcija, osim razvojnim bolestima i stanjima, može biti uzrokovano bilo kojom stečenom ozljedom mozga, kao što je, primjerice, moždani udar, trauma mozga, tumorske tvorbe mozga ili upalne bolesti moždanih ovojnica. Unatoč brojnim istraživanjima u kojima su dokumentirane učestalost i varijabilnost izvršnih poremećaja, njihovi temeljni mehanizmi i srodne specifične anatomske strukture ostaju uglavnom neodređene. Prema Roussel i sur. ${ }^{21}$, predložena su tri glavna objašnjenja za teškoće koje nastaju kao posljedica oštećenja izvršnih funkcija: deficiti nadzornog sustava koji je uključen u kontrolu djelovanja ${ }^{22}$, deficit pažnje i kontinuirane budnosti ${ }^{23}$ i poremećaj radnog pamćenja ${ }^{24}$. Iz perspektive okupacijske izvedbe, osobe s oštećenjem izvršnih funkcija osim teškoća u započinjanju aktivnosti nerijetko pokazuju i teškoće planiranja te s time povezane teškoće izvođenja pojedinih faza određene aktivnosti, kao i teškoće u prelasku s jedne aktivnosti na drugu. Naime, budući da nisu u stanju planirati kako će obavljati određeni zadatak, njihove se akcije nerijetko čine kao niz nepovezanih koraka, pri čemu se mogu uočiti poteškoće u određivanju redoslijeda koraka zadatka, kao i neučinkovito iskorištavanje vremena. Dodatno, teškoću pri izvedbi aktivnosti predstavlja i otežano praćenje slijeda koraka aktivnosti, pribora koji se trenutačno upotrebljava i koji je potreban za zadatak, kao i same svrhe zadatka. Klijent se stoga doima dezorijentiranim te je tek uz kontinuiranu podršku ili uz znatne teškoće u stanju provesti zadatak do kraja. Spomenute se teškoće, uz nemogućnost formuliranja namjera i nedostatak uvida, odražavaju na opće smanjenje inicijative, što negativno djeluje na okupacijsku izvedbu i produktivnost oboljele osobe. Štoviše, varijabilnost u manifestacijama oštećenja izvršnih funkcija može biti vidljiva kroz promjenu ličnosti pojedinca, njegovih životnih iskustava i intelekta, što se posljedično može odraziti na znatne izazove u participaciji u svakodnevnim životnim okupacijama.

U praksi je dostupan širok raspon standardiziranih neuropsiholoških testova za pojašnjenje vrste i opsega disfunkcije prefrontalnog korteksa koji se provode $u$ kontroliranim uvjetima. Unatoč tome, Burgess i sur. ${ }^{25}$ navode kako je većina neuropsiholoških testova nedovoljno obuhvatna pri mjerenju ovih teškoća jer integrirane izvršne funkcije razdvajaju u sastavne dijelove. Općenito, tradicionalni neuropsihološki testovi u analizi funkcije mozga slijede pristup usmjeren na simptome, pri čemu 
prikupljaju informacije o specifičnim aspektima spoznaje, kao što su pamćenje, planiranje ili pažnja. Premda takva procjena pruža informaciju o mjerenim kognitivnim oštećenjima, odnos pojedinih spoznajnih komponenata i neovisnosti u svakodnevnim okupacijama ostaje nejasan. Izvedba pojedinih zadataka u većini slučajeva u pozadini krije niz različitih procesa, što znači da zadatkom za koji smatramo da mjeri sposobnost planiranja gotovo sigurno mjerimo i neke druge aspekte izvršnih funkcija ${ }^{26}$. Stoga ove procjene još uvijek predstavljaju izazov brojnim stručnjacima zbog slabe prediktivnosti za uspješnost u stvarnim, kompleksnim, životnim aktivnostima. Primjer je jedne od često korištenih neuropsiholoških procjena u svrhu detekcije oštećenja izvršnih funkcija Wisconsin Card Sorting Test (WCST ${ }^{27}$ ) u kojem se od klijenta zahtijeva slaganje karata prema jednom od tri kriterija - boji, broju ili obliku. Klijent potom metodom pokušaja i pogreške mora detektirati strategiju prema kojoj su karte posložene, što čini svaki put kada eksperimentator iznenada i bez upozorenja promijeni strategiju. Lošija izvedba na testu smatra se tendencijom ustrajanja na pogrešnoj strategiji u situaciji promijenjenih okolnosti. Međutim, osim izvršnih funkcija, u rješavanje ovog testa uključene su i neke niže kognitivne funkcije, a samim time aktiviraju se i različita kortikalna i supkortikalna područja mozga te posebno mali mozak ${ }^{28}$, što ovu procjenu čini manjkavom u izučavanju oštećenja izvršnih funkcija. Osim toga, sudjelovanje u svakodnevnim aktivnostima i izvršne sposobnosti potrebne za njihovo obavljanje zahtijevaju obavljanje više zadataka najednom te generalizaciju i primjenu adaptivnih strategija kako bi se prilagodili novim situacijama i izveli zadatke u stvarnom okružju ${ }^{29}$. Upravo se navedeno u stručnoj literaturi navodi kao opća zamjerka neuropsihološkim testovima, čiji rezultati ne prikazuju stvarnu funkcionalnu sposobnost osobe ni izvedbu složenih zadataka u realnoj okolini ${ }^{25}$. Stoga, kada je riječ o oštećenju izvršnih procesa, možemo izvesti zaključak kako bi se rezultati procjene izoliranih značajki trebali nadopuniti procjenama značajki usmjerenih na izvedbu okupacije, koje uključuju zadatke iz stvarnog konteksta pojedinca, što im daje ekološku valjanost, jednu od krucijalnih karakteristika testova u kognitivnoj rehabilitaciji.

Okupacijska perspektiva zdravlja temeljni je koncept koji je razradila Ann A. Wilcock, a govori o snažnoj povezanosti okupacija* i zdravlja ${ }^{30}$. Ova je hipoteza potaknu-

\footnotetext{
* U ovom kontekstu okupacijama se smatraju sve svakodnevne aktivnosti kojima se ljudi bave, u koje se više ili manje aktivno uključuju, koje zaokupljaju i strukturiraju njihovo vrijeme, pažnju, energiju i ostale resurse te koje za svakog pojedinca imaju osobno $i$ kulturološko značenje i vrijednost.
}

la razvoj drugih teorija koje imaju zajedničku premisu o uključenosti u svakodnevne okupacije kao snažnom mjerilu zdravlja i dobrobiti, ali i istraživanja o tome kako se okupacije razvijaju i mijenjaju tijekom života, organiziraju naše ponašanje i daju mu smisao, kakva je interakcija osobe, okupacije i okoline te terapijski učinak okupacija. U kontekstu izvršnih funkcija kao dijela neurološkog sustava koji upravlja izvedbom svakodnevnih aktivnosti/okupacija razvidno je da ih neprekidno upotrebljavamo za kontrolu i koordinaciju nižih kognitivnih sposobnosti i ponašanja te nam kao takve omogućavaju izvedbu novih zadataka u cijelosti te uspješno sudjelovanje u svakodnevnim okupacijama. Prema tome, procjene koje sagledavaju teškoće u izvršnim funkcijama iz okupacijske perspektive usmjeravaju se na procjenu mogućnosti sudjelovanja u svakodnevnim okupacijama, a razvijaju se uglavnom u području radne terapije. U svrhu uvida u sposobnosti, ograničenja i izazove s kojima se susreće osoba s kognitivnim teškoćama pri obavljanju životnih okupacija razvijeno je nekoliko radnoterapijskih procjena, kao što su Allen baterija testova kognitivne razine (Allen Cognitive Levels Test Battery ${ }^{31}$ ), Procjena motoričkih vještina i vještina procesiranja (Assessment of Motor and Process Skills, AMPS ${ }^{32}$ ) i Bihevioralna procjena sindroma oštećenja izvršnih funkcija (Behavioural Assessment of Dysexecutive Syndrome, BADS $^{33}$ ). lako ove procjene identificiraju kognitivne deficite i teškoće u izvedbi aktivnosti, nemaju razvijen sustav bilježenja sposobnosti pojedinca uz progresivne razine neverbalnog ili verbalnog poticanja ili navođenja pri izvedbi zadatka ${ }^{34}$. Primjerice, takav sustav navođenja koji obuhvaća širi opseg sposobnosti sadrži Procjena zadatka u kuhinji (Kitchen Task Assessment, KTA ${ }^{35}$ ). Navedena procjena kroz jednostavnu aktivnost kuhanja pruža uvid u klijentove sposobnosti započinjanja, organizacije i završavanja aktivnosti, sekvencioniranja te sigurnosti. Međutim, s obzirom na kompleksnost izvršnih procesa, primarni nedostatak ove procjene sastoji se u procjeni klijentove izvedbe na samo jednom zadatku ${ }^{35}$. Literatura posljednjeg desetljeća podupire navode da su procjene izvršnih procesa najučinkovitije u stvarnim svakodnevnim zadacima i realnoj okolini ${ }^{25,36}$ jer omogućuju bolje razumijevanje utjecaja okolinskih čimbenika na izvedbu ${ }^{25}$. Na tom su temelju Carolyn Baum i njezini suradnici razvili Test izvedbe izvršnih funkcija (Executive Function Performance Test; EFPT ${ }^{37}$ ), koji će biti detaljnije prikazan u ovom radu. 


\section{Metode}

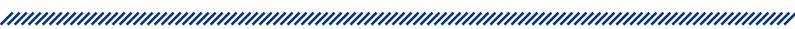

Cilj je ovog rada analizirati okupacijsku izvedbu osobe s teškoćama izvršnih funkcija primjenom standardizirane procjene kojom se ispituje sposobnost primjene izvršnih funkcija u kontekstu aktivnosti svakodnevnog života. Upotrijebljena je procjena Test izvedbe izvršnih funkcija ${ }^{37}$, a prikazana je kroz prikaz slučaja ženske osobe nakon operacije frontalnog meningeoma.

\subsection{Instrument}

Test izvedbe izvršnih funkcija (Executive Function Performance Test; EFPT $^{37}$ ) standardizirana je procjena viših kognitivnih funkcija utemeljena na okupacijskom pristupu u cilju ispitivanja funkcioniranja u okolini kroz integraciju izvršnih funkcija ${ }^{38}$. S obzirom na to da se većinom testova mjeri neuropsihološki deficit, EFPT ima dodanu vrijednost budući da ne procjenjuje samo ono što pojedinac nije u stanju učiniti, već procjenjuje klijentove očuvane sposobnosti, odnosno ono što može uspješno izvršitij ${ }^{34}$. Stoga se u EFPT-u primjenjuje sustav (ne)verbalnog navođenja kao podrška izvedbi zadatka koji je u korelaciji s razinom kognitivnog oštećenja. Navedeni standardizirani sustav navođenja omogućava identifikaciju šireg spektra sposobnosti kod osoba koje možda ne bi mogle izvršiti zadatak bez dodatne pomoći, što ukazuje na osjetljivost testa i na lošiju izvedbu uzrokovanu samom progresijom bolesti.

Test izvedbe izvršnih funkcija procjenjuje izvedbu kroz četiri osnovna zadatka s kojima se osoba susreće u svakodnevnom životu: jednostavno kuhanje, korištenje telefonom, uzimanje lijekova te plaćanje računa. Pri obavljanju zadatka „Jednostavno kuhanje” od klijenta se očekuje priprema zobene kaše slijedeći upute na pakiranju (ili prema receptu pripremljenom na papiru, dovoljno uvećanom i jasnom). „Korištenje telefonom” uključuje pretraživanje telefonskog imenika u svrhu pronalaska broja obližnje trgovine s povrćem, nazivanje trgovine te upit o dostavljanju povrća. Zadatak „Uzimanje lijekova” zahtijeva odabir propisanog lijeka među ponuđenima te uzimanje lijeka prema uputama (u bočici se nalazi bombon bez šećera). Kako bi se kod klijenta provjerile sposobnosti za obavljanje zadatka „Plaćanje računa”, uz dva računa u prozirnu plastičnu vrećicu potrebno je staviti još pet pošiljki, a bilancu i uplatnice staviti u kutiju s priborom. Od klijenta se zatim zatraži da izdvoji račune, plati in te izračuna stanje bilance.
Cjeloviti popis detaljno opisanog pribora sastavni je dio priručnika testa. Zadatak je terapeuta prikupiti sav pribor na temelju uputa navedenih u priručniku te ga smjestiti u kutiju dimenzija $70 \times 40 \times 30 \mathrm{~cm}$. Klijent iz kutije izdvaja potreban pribor ovisno o zahtjevima pojedinog zadatka/aktivnosti.

$\mathrm{U}$ svakom od navedena četiri zadatka test procjenjuje pet sastavnica izvršnih funkcija (v. tablicu 2): (1) inicijaciju/započinjanje aktivnosti, (2) organizaciju, (3) sekvencioniranje / izvršavanje koraka ispravnim redoslijedom, (4) prosudbu i sigurnost te (5) završavanje aktivnosti. Procjeni navedenih izvršnih funkcija prethodi zadatak „Pranje ruku” koji se primjenjuje samo u slučaju prisutnosti znatnih kognitivnih teškoća, radi uvida u klijentove sposobnosti slijeđenja uputa. S obzirom na to da je to trijažni zadatak, ne ocjenjuje se u bodovnoj analizi, a ako ga klijent nije sposoban izvesti (potrebna mu je pomoć na razini navođenja „Izvršenje umjesto sudionika"), cijela se procjena prekida jer se smatra da ne postoji potencijal za aktivno sudjelovanje u idućim zahtjevnijim zadacima.

Sastavnice izvršnih funkcija koje se mjere procjenom EFPT detaljno su opisane u priručniku ${ }^{37}$, a ovdje ih navodimo samo taksativno kako bi se mogao pratiti prikaz rezultata: (a) inicijacija ili započinjanje s aktivnošću, zatim izvršenje svakog koraka zadatka, koje obuhvaća: (b) organizaciju prostora i pribora, (c) sekvencioniranje ili ispravnu i koordiniranu izvedbu slijeda koraka zadatka i (d) rasuđivanje ili donošenje odluka o provedbi zadatka te sigurnost izvedbe zadatka, a potom i (e) primjereno završavanje zadatka.

Test sadrži detaljan sustav uputa za (ne)verbalno navođenje koji je standardiziran i povezan s razinom kognitivnog oštećenja, što znači da viši rezultat predstavlja i veću potrebu za smjernicama te indicira prisutnost ozbiljnijeg deficita izvršnih funkcija ${ }^{34}$. Ako klijent zatraži fizičku pomoć opravdanu prisutnim motoričkim deficitom, njegova se izvedba ne penalizira ${ }^{34}$. Autori testa navode pet razina pomoći koje su navedene i obrazložene u tablici 1.

Kod bilježenja rezultata evidentira se najviša razina pomoći nužna za izvedbu. Bodovi za sastavnice izvršnih funkcija računaju se sumiranjem bodova na svakom od četiri zadatka za inicijaciju, organizaciju, sekvencioniranje, rasuđivanje i sigurnost te završavanje aktivnosti. (Napomena: zadatak „Pranje ruku” služi kao trijažni test te se ne ocjenjuje.) Svaka izvršna sastavnica može se bodovati od 0 do 5 bodova, s ukupnim zbrojem za sve četiri aktivnosti od 0 do 20 bodova. Drugi bodovni rezultat, ocjenjivanje izvedbe zadatka, računa se zbrajanjem 


\begin{tabular}{|c|c|c|}
\hline Razina navođenja & Bod & Opis navođenja \\
\hline Poticaji nisu potrebni & 0 & Klijent je samostalan u izvedbi \\
\hline $\begin{array}{l}\text { Neizravno verbalno } \\
\text { navođenje }\end{array}$ & 1 & $\begin{array}{l}\text { Postavljeno u obliku otvorenog pitanja ili potvrđivanja (npr. „Što je još } \\
\text { potrebno?”, „Koji je sljedeći korak?”) }\end{array}$ \\
\hline Navođenje gestikulacijom & 2 & $\begin{array}{c}\text { Gestikulirati samo na način koji oponaša postupak potreban za nastavak } \\
\text { zadatka (npr. pokazati smjer, imitirati pokret miješanja i sl.) }\end{array}$ \\
\hline Izravna verbalna pomoć & 3 & Izravni verbalni nalog (npr. „Uzmite olovku.” i sl.) \\
\hline Fizička pomoć & 4 & $\begin{array}{l}\text { Fizička pomoć u koraku zadatka (npr. držati uplatnicu dok sudionik piše, } \\
\text { držati čašu dok sudionik ulijeva i sl.) }\end{array}$ \\
\hline $\begin{array}{l}\text { Izvršenje umjesto } \\
\text { ispitanika }\end{array}$ & 5 & Nakon pomoći sudionik se ne vraća na zadatak. \\
\hline
\end{tabular}

pet rezultata svakog zadatka, a raspon je za svaki zadatak od 0 do 25 bodova. Ukupni rezultat zbroj je bodova izvedbe sva četiri zadatka, a može se kretati u rasponu od 0 do 100 bodova ${ }^{38}$.

Carolyn Baum sa suradnicima ${ }^{34}$ provjeravala je psihometrijske osobine testa EFPT na uzorku od 73 sudionika, u skupini osoba koje su pretrpjele moždani udar prije šest mjeseci (podijeljenih u dvije podskupine s blažim i umjerenim posljedicama moždanog udara) te kontrolnoj skupini. Koeficijent korelacije koji označava pouzdanost ispitivača za cjelokupni test iznosio je $r=0,91$, dok su se za podtestove koeficijenti kretali u rasponu od $r=0,87$ (za podtest uzimanja lijekova) do $r=0,94$ (za podtest zadatak kuhanja). Za cijeli uzorak koeficijent pouzdanosti unutarnje konzistencije iznosio je $\alpha=0,94$. Korelacije pojedinih testnih domena i ukupnog rezultata iznosile su od $r=0,78$ (sigurnost i rasuđivanje) do $r=0,93$ (organizacija). Konstruktna valjanost potvrđena je statistički značajnim razlikama u bodovima izvedbe zadatka među svim skupinama sudionika, pri čemu je očekivana najlošija izvedba skupine s umjerenim posljedicama moždanog udara, a najbolja izvedba kontrolne skupine. Jedino u zadatku kuhanja nije pronađena razlika u dvije skupine sudionika s moždanim udarom (slabija osjetljivost). Kriterijska valjanost ispitana je usporedbom rezultata testa EFPT s rezultatima na dva testa oštećenja sposobnosti, četiri neuropsihološka testa i dva testa funkcionalne izvedbe $u$ aktivnostima svakodnevnog života: Functional Independence Measure ${ }^{39}$ i Functional Assessment Measure $^{40}$. Sve su korelacije bile umjerene i značajne, osim za dva neuropsihološka testa (Trailmaking Test, Reitan i Wolfson, 1995. i Digit Span Forward, podtest ljestvice Wechsler Memory Scale - Revised, 1987., sve prema ${ }^{34}$ ).
Ovakvi rezultati potvrđeni su i u kasnijem istraživanju s osobama koje su pretrpjele moždani udar unazad tjedan dana ${ }^{38}$. Psihometrijske osobine ovog testa provjerene su i s drugim skupinama kliničkih sudionika. Goverover i Chiaravalloti ${ }^{42}$ potvrdili su valjanost na uzorku odraslih osoba oboljelih od multiple skleroze, dok su Katz i suradnici ${ }^{43}$ valjanost, pouzdanost i osjetljivost procjene potvrdili kod osoba sa shizofrenijom.

Nisu nam dostupna istraživanja o pouzdanosti procjene EFPT pri ispitivanju osoba oboljelih od tumora u predjelu čeonog režnja, no u literaturi se nalaze podaci o promjenama ličnosti i kognitivnog funkcioniranja za-

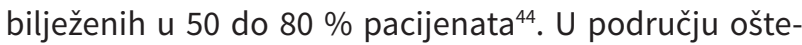
ćenja izvršnih funkcija zbog tumorskih tvorbi najčešće su neoplazme povezane s kognitivnim poremećajima meningeomi, a ako se nalaze u čeonom području, kao u slučaju prikazanom u ovom radu, mogu dovesti do agresivnog i impulzivnog ponašanja, iritabilnosti te znatnog smanjenja ili odsutnosti motivacije i interesa ${ }^{45}$. Dakle, riječ je o posljedicama oštećenja izvršnih funkcija koje uvelike utječu na funkcionalnost u aktivnostima dnevnog života oboljele osobe.

Primjena testa izvedbe izvršnih funkcija bit će prikazana kroz prikaz slučaja odrasle osobe nakon operacije frontalnog meningeoma. Procjena EFPT prevedena je s engleskog na hrvatski jezik na Odjelu za radnu terapiju Specijalne bolnice za medicinsku rehabilitaciju Krapinske Toplice, uz pismenu suglasnost prve autorice testa**.

\footnotetext{
** Ovdje posebno zahvaljujemo prof. Carolyn M. Baum na ustupanju procjene te Ivani Klepo, bacc. therap. occup. s Odjela za radnu terapiju Specijalne bolnice za medicinsku rehabilitaciju Krapinske Toplice na pruženoj pomoći prilikom primjene testa EFPT.
} 
Riječ je o testu koji je dostupan na mrežnim stranicama Washington University School of Medicine; Occupational Therapy, Rehabilitation and Participation Science. S obzirom na to da su u originalnoj verziji procjene zadaci precizno objašnjeni i kao takvi zahtijevaju upotrebu točno određenog pribora, provedba testa uključivala je određene prilagodbe. Konkretno, zadatak „Korištenje telefonom" proveden je tako da je klijentica, umjesto lokalne trgovine s povrćem, nazvala fizioterapeuta i pitala ga hoće li je odvesti na sljedeću terapiju. Stoga nije upotrebljavan telefonski imenik priložen testnom instrumentariju, no u svrhu očuvanja valjanosti procjene klijentica je broj, kao što je predviđeno originalnom verzijom testa, morala samostalno pronaći među brojevima ostalih zaposlenika bolnice. Razlog navedenoj prilagodbi bila je nemogućnost upućivanja poziva izvan ustanove s internih telefonskih linija, a na ovaj se način osigurala podjednaka zahtjevnost zadatka. Osim ove prilagodbe, test je proveden u cijelosti u izvornom obliku.

\section{Rezultati}

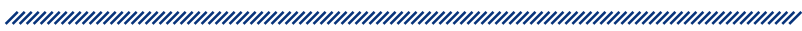

\subsection{Prikaz slučaja}

Ženska osoba u dobi od 67 godina liječena je u Klinici za neurokirurgiju sredinom 2014. godine te je potom premještena $u$ jednu od specijalnih bolnica za medicinsku rehabilitaciju. Anamneza ukazuje kako je razlog boravka na Odjelu za neurološku rehabilitaciju frontalna osteoplastična kraniotomija i ablacija meningeoma (Simpson II.). Do operativnog liječenja doveli su rezultati MR-a mozga, koji su ukazivali na meningeom olfaktornog žlijeba u prednjoj lubanjskoj jami, veličine $4,0 \times 3,3 \times 3,0 \mathrm{~cm}$ te malatične promjene parenhima čeonih režnjeva. Pri primitku stručnjaci nisu primijetili dodatne medicinske komplikacije, što potvrđuju i navodi pacijentice. $U$ radnoterapijskom nalazu zabilježene su smetnje inicijacije (započinjanja) aktivnosti i koraka aktivnosti te teškoće pri završavanju zadataka. Osim toga, pacijentica je usporena u izvedbi, a pomoć terapeuta potrebna je pri obavljanju aktivnosti samozbrinjavanja. Iz radnoterapijskog intervjua saznaje se da je umirovljena, održava kućanstvo i vrt, no navodi kako više nije motivirana kao nekad. Uz to, brzo se umara pa joj je potrebno i mnogo više vremena za izvršavanje obveza. Prema njezinim riječima, upravo su te teškoće i bile poticaj za posjet neurologu. Osjećala je i slabost u nogama, uz učestale grčeve te česte glavobolje u čeonom predjelu. Na rehabilitaciji je četiri tjedna, a radna terapeutkinja navodi kako je oporavak na određenim područjima jasno vidljiv. U kontekstu ovog rada, još se uvijek primjećuje usporenost pri obavljanju aktivnosti te smanjena motivacija za rad.

\subsection{Rezultati provedenog testa EFPT}

Kao trijažni test, prije formalne procjene izvršnih funkcija, primijenjena je tehnika „scenarij planiranja”, pri čemu je klijentica imala zadatak isplanirati iduće druženje $s$ unucima. Riječ je o hipotetskom planiranju tijekom kojeg terapeut opaža komponente izvršnih funkcija, kao što su odabir ciljeva, planiranje i sekvencioniranje, organizaciju i vremensku orijentaciju. U ovom zadatku terapeut postavlja pitanja povezana sa spomenutom temom na način da odgovori klijentice ukazuju na navedene komponente izvršnih funkcija (npr. vremenska orijentacija ispitana je pitanjima „Kojeg će dana biti druženje?”, „U koliko sati?”, „Koliko mislite da će druženje trajati?” i sl.). Svrha je ovog zadatka relativno brz uvid u kognitivni status klijentice s naglaskom na više kognitivne funkcije. $U$ ovom zadatku pacijentica je uspješna, no budući da se korišteni test temelji na subjektivnoj procjeni terapeuta te da su na početku rehabilitacije primijećene teškoće inicijacije i završavanja aktivnosti, u nastavku je primijenjen Test izvedbe izvršnih funkcija.

Kako je predviđeno u sklopu procjene EFPT, na samom se početku klijentici postavlja nekoliko pitanja koja služe procjeni vlastite učinkovitosti u zadacima koji slijede. Ova inicijalna samoprocjena važna je kao mjera svjesnosti pojedinca o vlastitim sposobnostima obavljanja poznatih zadataka, ali i kao potencijalni izvor poteškoća zasnovanih u njegovoj trenutačnoj razini sposobnosti. U skladu s time, klijentica navodi kako je kod kuće samostalno kuhala i upotrebljavala štednjak, ali da nije kuhala zobenu kašu te smatra kako bi to mogla učiniti uz verbalno vođenje. Telefonom se koristi nekoliko puta tjedno, može samostalno obaviti poziv, a u slučaju nužde zvala bi policiju, iako ne zna pozivni broj. Uzima lijekove više puta dnevno, zna gdje se nalaze i smatra da ih može samostalno uzimati. Kod kuće je samostalno plaćala račune, no sada smatra da joj je potrebno verbalno vođenje.

Premda procjena EFPT, u skladu s brojem zadataka, uključuje pet obrazaca za bilježenje rezultata, u nastavku 
su prikazani samo rezultati izvedbe zadatka pranja ruku (tablica 2). Svrha prikaza samo jednog originalnog obrasca procjene EFPT jest stjecanje uvida u detaljan opis zadatka i onog što se od klijenta očekuje, čime se ujedno osiguravaju detaljne upute za bodovanje. Pritom bodovi imaju značenje koje je navedeno u tablici 1.

Sažete tablice ukupnih bodova pojedinih komponenata izvršnih funkcija te izvedbe pojedinog zadatka prikazane su u tablicama 3 i 4.

\section{Diskusija}

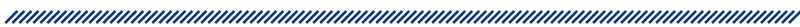

Prema Baum i sur. ${ }^{38}$, tri su svrhe procjene EFPT: (1) otkrivanje prisutnih izvršnih teškoća, (2) određivanje sposobnosti pojedinca za samostalno funkcioniranje i (3) određivanje razine pomoći potrebne za izvršenje određenog zadatka. Primjenom ovog testa s osobom koja pati od posljedica meningeoma uočene su teškoće u organizaciji i izvršavanju koraka u odgovarajućem redoslijedu, što se razlikuje od inicijalne radnoterapijske procjene, tijekom koje su uočene teškoće u započinjanju aktivnosti i njezinih pojedinih koraka te završavanju aktivnosti. Cahn-Weiner, Boyle i Malloy ${ }^{46}$ navode kako je, kada je riječ o započinjanju zadatka i donošenju odluka, procjena terapeuta primjerenija od procjene

\section{Tablica 2. Test izvedbe izvršnih funkcija (EFPT): Obrazac A}

\begin{tabular}{|c|c|c|c|c|c|c|c|}
\hline ZADATAK: Pranje ruku & 0 & 1 & 2 & 3 & 4 & 5 & Rezultat \\
\hline \multicolumn{8}{|l|}{ INICIJACIJA: započinjanje zadatka } \\
\hline Na zahtjev da se započne, sudionik odlazi do stola kako bi uzeo stvari za pranje ruku. & $x$ & & & & & & 0 \\
\hline \multicolumn{8}{|l|}{$\begin{array}{c}\text { IZVRŠENJE: provođenje postupaka zadatka primjenom organizacije, sekvencioniranja i } \\
\text { prosuđivanja }\end{array}$} \\
\hline $\begin{array}{l}\text { Organizacija: razmještaj stvari potrebnih za završetak zadatka } \\
\text { Sudionik uzima potrebne stvari (sapun, ručnik). }\end{array}$ & $\mathrm{x}$ & & & & & & 0 \\
\hline $\begin{array}{l}\text { Sekvencioniranje: izvršavanje koraka prema odgovarajućem redoslijedu } \\
\text { Sudionik obavlja korake u odgovarajućem slijedu: } \\
\text { npr. otvara vodu, uzima sapun, trlja ruke, ispire ruke, zatvara vodu, poseže za ručnikom i } \\
\text { suši ruke. Sudionik ne miješa korake: npr., suši ruke prije nego što ih je oprao, upotrebljava } \\
\text { sapun prije nego što su ruke mokre itd. }\end{array}$ & & $\mathrm{x}$ & & & & & 1 \\
\hline $\begin{array}{l}\text { Rasuđivanje i sigurnost: izbjegavanje opasnih situacija } \\
\text { Sudionik sprječava ili izbjegava opasnosti: npr., temperatura vode nije previsoka, izbjegava } \\
\text { izlijevanje vode po podu, ne jede sapun itd. }\end{array}$ & $\mathrm{x}$ & & & & & & 0 \\
\hline \multicolumn{8}{|l|}{ ZAVRŠETAK: završavanje zadatka } \\
\hline Sudionik zna da je završio: npr., prestaje sušiti ruke / zatvorio je vodu. & & & & $x$ & & & 3 \\
\hline UKUPNI REZULTAT & & & & & & & 4 \\
\hline
\end{tabular}

\begin{tabular}{|c|c|c|c|c|c|}
\hline \multicolumn{7}{|c|}{ Tablica 3. Prikaz rezultata pojedinih komponenata izvršnih funkcija } \\
\hline \multirow{2}{*}{ Sastavnice izvršnih funkcija } & \multicolumn{3}{|c|}{ Bodovi } & UKUPNO \\
\cline { 2 - 6 } & $Z 1$ & $Z 2$ & $Z 3$ & $0 / 5$ & $0 / 20$ \\
\hline Inicijacija & $0 / 5$ & $0 / 5$ & $0 / 5$ & $3 / 5$ & $4 / 20$ \\
\hline Organizacija & $1 / 5$ & $0 / 5$ & $0 / 5$ & $0 / 5$ & $3 / 20$ \\
\hline Sekvencioniranje & $0 / 5$ & $3 / 5$ & $0 / 5$ & $0 / 5$ & $0 / 20$ \\
\hline Procjena i sigurnost & $0 / 5$ & $0 / 5$ & $0 / 5$ & $0 / 5$ & $0 / 20$ \\
\hline Završetak & $0 / 5$ & $0 / 5$ & $0 / 5$ & \\
\hline
\end{tabular}




\begin{tabular}{|c|c|c|c|}
\hline ZADATAK & Sastavnice izvršnih funkcija & BODOVI & UKUPNO \\
\hline \multirow{5}{*}{ Jednostavno kuhanje } & Inicijacija & $0 / 5$ & \multirow{5}{*}{$1 / 25$} \\
\hline & Organizacija & $1 / 5$ & \\
\hline & Sekvencioniranje & $0 / 5$ & \\
\hline & Procjena i sigurnost & $0 / 5$ & \\
\hline & Završetak & $0 / 5$ & \\
\hline \multirow{5}{*}{ Korištenje telefonom } & Inicijacija & $0 / 5$ & \multirow{5}{*}{$3 / 25$} \\
\hline & Organizacija & $0 / 5$ & \\
\hline & Sekvencioniranje & $3 / 5$ & \\
\hline & Procjena i sigurnost & $0 / 5$ & \\
\hline & Završetak & $0 / 5$ & \\
\hline \multirow{5}{*}{ Uzimanje lijekova } & Inicijacija & $0 / 5$ & \multirow{5}{*}{$0 / 25$} \\
\hline & Organizacija & $0 / 5$ & \\
\hline & Sekvencioniranje & $0 / 5$ & \\
\hline & Procjena i sigurnost & $0 / 5$ & \\
\hline & Završetak & $0 / 5$ & \\
\hline \multirow{5}{*}{ Plaćanje računa } & Inicijacija & $0 / 5$ & \multirow{5}{*}{$3 / 25$} \\
\hline & Organizacija & $3 / 5$ & \\
\hline & Sekvencioniranje & $0 / 5$ & \\
\hline & Procjena i sigurnost & $0 / 5$ & \\
\hline & Završetak & $0 / 5$ & \\
\hline UKUPNO & & & $7 / 100$ \\
\hline
\end{tabular}

testovima koji zahtijevaju izvedbu zadataka. Smatraju da su takve procjene svojom strukturom određeni vanjski poticaj te tako smanjuju zahtjeve za samostalno započinjanje izvođenja zadatka i donošenje odluka. Štoviše, prema Katz i sur. ${ }^{43}$, veliki nedostatak procjene EFPT odnosi se upravo na započinjanje aktivnosti jer, iako pruža naznaku inicijacije u svakom koraku zadatka, nije dovoljno osjetljiva za mjerenje ukupne inicijacije potrebne u svakodnevnom životu, bez postojanja vanjskih poticaja i uputa. Time, ali i uspješnom rehabilitacijom, mogla bi se objasniti nepodudarnost inicijalne radnoterapijske procjene i rezultata na Testu izvedbe izvrših funkcija. Zanimljivo je da trijažni zadatak potvrđuje spomenute teškoće u završavanju zadatka, međutim pri izvršavanju preostalih aktivnosti takve teškoće nisu zabilježene. Dakle, kako bi završila zadatak pranja ruku, bile su potrebne izravne verbalne upute (3), s obzirom na to da klijentica nije zatvorila vodu. Katz i sur. ${ }^{43}$ $\mathrm{u}$ istraživanju u kojem su primjenjivali procjenu EFPT s osobama oboljelima od shizofrenije navode kako je za- vršavanje zadatka važan korak u izvedbi, međutim ne može biti jasna sastavnica izvršnih funkcija kao što su to planiranje i/ili samoregulacija. Svoj zaključak temelje na dobivenoj visokoj unutarnjoj pouzdanosti procjene te na činjenici da je korelacija najmanja upravo za tu komponentu izvršnih funkcija.

Nadalje, teškoće u sekvencioniranju, osim u trijažnom zadatku, zabilježene su i pri korištenju telefonom. Zadatak je bio prilagođen uvjetima rada, no sastojao se od istih koraka (traži broj, diže slušalicu, bira broj, dobiva točan broj i postavlja ispravno pitanje). Za razliku od zadatka iz procjene EFPT, u prilagođenoj je verziji test umjesto u telefonskom imeniku zahtijevao pronalazak broja na papiru zalijepljenom na telefon, a umjesto pitanja „Dostavljate li povrće?" klijentica je trebala pitati terapeuta hoće li je odvesti na sljedeću terapiju. Prilikom izvedbe zadatka najprije je podigla slušalicu pa tek nakon nekog vremena krenula tražiti broj, a u drugom pokušaju pronašla je broj te ga počela birati prije negoli je uopće podignula slušalicu. Nakon izravne verbalne upute (3) pomoć više nije 
bila potrebna i klijentica je samostalno završila zadatak. Korištenje telefonom univerzalno je poznata aktivnost i prema tome bi trebala biti lako izvediva, stoga je ovaj rezultat teško interpretirati. Budući da nemamo jasne, objektivne podatke o predoperacijskom ni o poslijeoperacijskom kognitivnom statusu klijentice, ne možemo odrediti specifične aspekte kognicije i iskustva klijentice te njihovu povezanost s izvedbom. S druge strane, zabilježene teškoće u organizaciji jednim su dijelom i otegotna strana ove procjene. Prema uputi iz testa, organizacija podrazumijeva razmještaj stvari potrebnih za izvršenje zadatka, a kao što je prethodno spomenuto, sav pribor nalazi se $u$ jednoj kutiji i ispitanik ga sam odabire, ovisno o aktivnosti koju obavlja. Na primjer, za zadatak kuhanja zobene kaše potrebno je uzeti lonac (s ručkom koja se zagrije i zahtijeva upotrebu rukavice), rukavicu, staklenu mjericu, suhe šalice za mjerenje, žlicu za miješanje, gumenu špatulu, zob, povećanu kopiju uputa za upotrebu štednjaka te upute za pripremu jela, žlicu, soljenku i sat s kazaljkama. Prvenstveno, svaka će osoba uzeti ono što misli da joj je potrebno pa su tako nekom dvije žlice i gumena špatula možda previše za pripremu jednostavnog jela kao što je zobena kaša te će uzeti samo jednu žlicu. $\mathrm{U}$ tom slučaju, prema autorici procjene, potrebna je pomoć terapeuta prema sustavu navođenja. Upravo takva situacija dogodila se u slučaju opisanom u ovom radu. Dakle, neizravno verbalno navođenje (1) bilo je potrebno kako bi klijentica uzela sav navedeni pribor, a u samoj izvedbi upotrebljavala je upute, lonac, rukavicu, jednu šalicu, jednu žlicu, soljenku i zob te zadatak završila bez potrebne pomoći. lako se kuhanje smatra kompleksnom aktivnošću, minimalna pomoć prema sustavu navođenja mogla bi upućivati na poznatost same aktivnosti, ali i na to da zadatak kuhanja zobene kaše sam po sebi nije dovoljno zahtjevan. Psihometrijski gledano, ovakvi se nalazi mogu objasniti i smanjenom osjetljivošću testa u zadatku kuhanja, na koju ukazuju raniji nalazij3. Ova objašnjenja također mogu biti argument za potpuno samostalnu izvedbu u zadatku uzimanja lijekova. Naime, Chaytor, Schmitter-Edgecombe i Burr ${ }^{47}$ navode kako osoba s oštećenjem izvršnih funkcija ne mora imati teškoće prilikom obavljanja svakodnevnih zadataka ako nisu zahtjevni. No ako jesu, čak će se i slaba oštećenja izvršnih funkcija odraziti na funkcionalnost, odnosno izvedbu. Uzimajući u obzir dosadašnju rehabilitaciju klijentice, može se pretpostaviti kako bi se oštećenje izvršnih funkcija lakše detektiralo kada bi zadaci bili složeniji.

Iste teškoće zabilježene su pri izvedbi zadatka plaćanja računa. U kutiji se nalazi sljedeći pribor: dva računa (jedan za kabelsku televiziju, jedan za telefon) pomiješana s još pet pošiljki (pismo iz banke, letak za rasprodaju i sl.) u prozirnoj plastičnoj vrećici, dvije uplatnice, bilanca (npr. izvod s računa sa stanjem 5,00 kuna manjim nego što iznosi ukupni zbroj svih računa), omotnica, poštanske marke, kemijska olovka i kalkulator, čija upotreba nije nužna. S obzirom na to da u današnje vrijeme omotnica i poštanske marke nisu potrebne pri plaćanju računa, izravne verbalne upute (3) mogu se opravdati potrebom za prilagodbom procjene. Također, zadatak plaćanja računa kompleksnije je prirode pa je prema tome razumljivo da bi osobama s oštećenjem izvršnih funkcija bila potrebna i veća pomoć pri izvršavanju.

Vidljivo je da su određeni nedostaci opravdani činjenicom da Test izvedbe izvršnih funkcija nije standardiziran u Hrvatskoj, što je zasigurno moglo utjecati na dobiveni rezultat. Naime, jednostavno kuhanje podrazumijeva kuhanje zobene kaše, što zapravo može postati složena aktivnost osobi kojoj kulturološki ta namirnica nije često u upotrebi. Zadatak bi stoga trebao biti kuhanje jela bližeg našoj kulturi (primjerice palente ili pšenične krupice). Za prilagodbu zadataka plaćanja računa u obzir bi trebalo uzeti način na koji to pojedinac inače obavlja, odnosno odlazi li u poštu/banku ili se služi računalom ili pametnim telefonom. $\cup$ oba je slučaja iz izvorne procjene potrebno izostaviti omotnicu i poštanske marke, a te korake zamijeniti eventualnim odlaskom do ciljne ustanove ili primjerenim slijedom koraka s obzirom na analizu te aktivnosti. Međutim, usprkos potrebi za prilagodbom procjene EFPT, može se zaključiti kako je njezina ekološka valjanost zadovoljavajuća budući da sastavnice, poput odabira potrebnih predmeta za izvedbu, razumijevanje svrhe omotnice i poštanske marke te njihova upotreba, u gotovo svim okruženjima odražavaju opće zadatke za čije je uspješno obavljanje nužna primjena različitih izvršnih funkcija.

Važno je naglasiti da test, umjesto usmjeravanja na teškoće, identificira klijentove jake strane, odnosno ono što pojedinac može učiniti. S obzirom na to da bi uz sustav navođenja većina ispitanika (nakon početne trijaže) trebala moći izvršiti zadatke, procjena pruža važne informacije za stupnjevanu terapijsku intervenciju, odnosno razinu podrške koja će osobi biti potrebna nakon hospitalizacije, po povratku u vlastiti dom. Ipak, sustav (ne)verbalnog navođenja prema kojem terapeut mora intervenirati ako klijent, primjerice, nije uzeo sav pribor koji nalažu upute testa, može predstavljati izazov. U pitanju su četiri različita zadatka i dakako da za pripremu zobene kaše neće biti potrebna kemijska olovka, no isto tako, s obzirom na deficite radnog pamćenja koji se uklapaju u simptomatologiju deficita izvršnih funkcija, 
nije za očekivati da klijent pamti zadatke koji ga očekuju u daljnjoj procjeni pa da prema tome metodom eliminacije odabire pribor. Također, određene predmete može doživjeti kao distraktore upravo zato što ih smatra suvišnima za uspješnu izvedbu zadatka. Povezano s time, postavlja se pitanje čemu zapravo služi kutija s priborom i kako se uklapa u ideju analize izvršnih funkcija u stvarnom, realnom okružju klijenta u kojem se pribor za različite svakodnevne zadatke ne nalazi izmiješan na jednom mjestu, već vjerojatno kategoriziran u odgovarajućem namještaju ili prostoru.

Zaključno, gledajući iz okupacijske perspektive, svakako preporučujemo da se procjena EFPT upotrebljava s drugim radnoterapijskim pristupima koji mogu dodatno diskriminirati poteškoće u izvršnim funkcijama s kojima se klijent suočava. To može biti standardizirana Procjena motoričkih vještina i vještina procesiranja (AMPS ${ }^{32}$ ) ili standardna analiza klijentu važne i smislene okupacije u kojoj će sigurno participirati povratkom u svoje prirodno okružje; dom i zajednicu. Te se okupacije mogu identificirati strukturiranim intervjuom, kao što je to Kanadska mjera izvođenja okupacija ili COPM ${ }^{49}$, te graduirati prema složenosti i zahtjevnosti u odnosu na izvršne funkcije nužne za njihovo izvršenje. Budući da je EFPT primarno konstruiran za osobe starije životne dobi s mogućom demencijom i da su određeni podtestovi slabije zahtjevni, preporučuju se dodatna istraživanja kako bi se bolje razumjela povezanost kognitivnih procesa i funkcionalne sposobnosti za aktivnosti dnevnog života osoba nakon operacije frontalnog meningeoma. Test izvedbe izvršnih funkcija potrebno je provesti na većem uzorku te na drugim populacijama, kako bi se uočeni izazovi u primjeni odbacili odnosno potvrdili ili korigirali. Također, preporučuje se primjena dodatne objektivne procjene specifičnih kognitivnih sposobnosti uz EFPT koju bi usporedili s rezultatima testa EFPT te ispitali cjelokupnu kognitivnu integraciju. Upoznatost sa spoznajnim čimbenicima koji pridonose uspješnoj izvedbi svakodnevnih aktivnosti i omogućuju je u velikoj bi mjeri pridonijela i uspješnijim intervencijama za osobe nakon operacije frontalnog meningeoma, kao i općenito za sve s navedenim teškoćama.

\section{Zaključak}

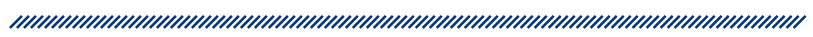

Izvršne su funkcije kognitivni, integrativni procesi nužni za sudjelovanje u svakodnevnim okupacijama, a za njihovu procjenu nije dovoljan samo segmentirani pristup koji pružaju neuropsihološki testovi, već i primijenjena razina ispitivanja uspješnosti u kompleksnim svakodnevnim zadacima i okupacijama. Cilj ovog rada bio je kroz prikaz slučaja analizirati prednosti i izazove primjene testa EFPT kako bi se ukazalo na mogućnost drugačije metode procjenjivanja izvršnih funkcija u kontekstu svakodnevnih aktivnosti. Analizom procjene kroz prikaz slučaja vidljivo je kako najveći izazov u primjeni testa predstavlja njegova (ne)prilagođenost hrvatskom kontekstu te opisi zadataka koji dozvoljavaju samo jedan način izvedbe. S obzirom na to da se sav potreban pribor uzima iz kutije, što obično nije slučaj u stvarnom životu, razina pomoći određena standardiziranim sustavom navođenja (posebno područje organizacije) nije nužno realna pomoć potrebna u svakodnevnom životu. Također, budući da raniji nalazi ukazuju na smanjenu osjetljivost u zadatku kuhanja, preporučuje se provjera psihometrijskih osobina zadatka, kako bi se potvrdila ili otklonila sumnja u nedostatnu osjetljivost procjene EFPT kod lakših i umjerenih oštećenja izvršnih funkcija. U tom slučaju predlažemo primjenu osjetljivijih testova u timskoj obradi te dodatne analize životnih okupacija temeljene na strukturiranoj opservaciji. Takav prijedlog dijelom je potaknut i nepodudarnošću inicijalne radnoterapijske procjene i rezultata procjene EFPT klijentice, pri čemu u obzir treba uzeti mogućnost da je dobiveni rezultat, koji ukazuje na manje izraženo oštećenje izvršnih funkcija, zapravo rezultat rehabilitacije kojoj je klijentica podvrgnuta. Ipak, procjena EFPT osigurala je detaljnu, objektivnu analizu izvršnih funkcija koje posreduju pri rješavanju svakog zadatka te pružila uvid u vrstu i količinu pomoći potrebnu za uspješno izvršavanje zadatka. lako rezultati ne ukazuju na znatna oštećenja izvršnih funkcija, procjena EFPT svakako je osigurala informacije o poslijerehabilitacijskoj podršci koja će klijentici biti potrebna u obiteljskom okružju. U skladu s time zaključujemo kako ovaj test ima potencijal za korištenje tijekom okupacijski orijentirane rehabilitacije, jer analizom izvedbe poznatih i svakodnevnih zadataka pruža uvid u klijentove snage, što je vrijedan podatak za daljnje radnoterapijske intervencije, čija je svrha poticanje lakšeg povratka u svakodnevne životne aktivnosti klijenta. 


\section{Literatura}

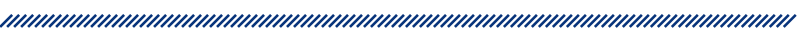

1. Barkley RA. Behavioral inhibition, sustained attention, and executive functions: constructing a unifying theory of ADHD. Psychol Bull. 1997; 121(1): 65-94.

2. Cicerone KD, Dahlberg C, Kalmar K, Langenbahn DM, Malec JF, Bergquist TF, et al. Evidence-based cognitive rehabilitation: Recommendations for clinical practice. Arch Phys Med Rehab. 2000; 81(12): 1596-1615.

3. Zoltan B. Vision, perception and cognition: A manual for the evaluation and treatment of the neurologically impaired adult. 3. izd. Thorofare, NJ: SLACK Inc; 1996.

4. Luria AR. Frontal lobe syndromes. U: Vinken PJ, Bruyn GW, editors. Handbook of clinical neurology. Amsterdam: North Holland; 1969. 725-757.

5. Damasio AR, Anderson SW. The frontal lobes. U: Heilman KM, Valenstein E, ur. Clinical neuropsychology. New York: Oxford University Press; 1993. 409-460.

6. Zelazo PD, Carter A, Reznick JS, Frye D. Early development of executive function: A problemsolving framework. Rev Gen Psychol. 1995; 1(2): 198-226.

7. Anderson P. Assessment and development of executive function (EF) during childhood. Child Neuropsychol. 2002; 8(2): 71-82.

8. Galić S. Neuropsihologijska procjena. Jastrebarsko: Naklada Slap; 2002.

9. Diamond A. Developmental time course in human infants and infant monkeys, and the neural bases of inhibitory control in reaching. Ann N Y Acad Sci. 1990; 608: 637-676.

10. Goldman-Rakic PS. Architecture of the prefrontal cortex and the central executive. U: Grafman J, Holyoak KJ, Boller F, ur. Structure and functions of the human prefrontal cortex. Ann N Y Acad Sci. 1995; 769: 71-84.

11. Stuss DT, Alexander MP. Executive functions and the frontal lobes: a conceptual view. Psychol Res. 2000; 63(34): 289-298.

12. Shallice T. Specific impairments of planning. Philos Trans R Soc Lond B Biol Sci. 1982; 298(1089): 199-209.

13. Takeuchi H, Taki Y, Sassa Y, Hashizume H, Sekiguchi A, Fukushima A, et al. Brain structures associated with executive functions during everyday events in a non-clinical sample. Brain Struct Funct. 2013; 218(4): 1017-1032.

14. Yogev-Seligmann G, Hausdorff JM, Giladi N. The role of executive function and attention in gait. Movement Disord. 2008; 23(3): 329-342.

15. Koechlin E, Danek A, Burnod Y, Grafman J. Medial prefrontal and subcortical mechanisms underlying the acquisition of motor and cognitive action sequences in humans. Neuron. 2002; 35(2): 371-381.

16. Bechara A, Damasio H, Damasio AR. Emotion, decision making and the orbitofrontal cortex. Cereb Cortex. 2000; 10(3): 295-307.
17. Beer JS, John OP, Scabini D, Knight RT. Orbitofrontal cortex and social behavior: integrating self-monitoring and emotion-cognition interactions. J Cognitive Neurosci. 2006; 18(6): 871-879.

18. Unterrainer JM, Owen AM. Planning and problem solving: From neuropsychology to functional neuroimaging. J Physiol Paris. 2006; 99(4-6): 308-317.

19. Yoon JH, Hoffman JN, D’Esposito M. Segregation of function in the lateral prefrontal cortex during visual object working memory. Brain Res. 2007; 1184: 217-225.

20. Moll J, de Oliveira-Souza R, Moll FT, Bramati IE, Andreiuolo PA. The cerebral correlates of setshifting: an fMRI study of the trail making test. Arq Neuropsiquiatr. 2002; 60(4): 900-905.

21. Roussel M, Dujardin K, Hénon H, Godefroy O. Is the frontal dysexecutive syndrome due to a working memory deficit? Evidence from patients with stroke. Brain. 2012; 135(7): 2192-2201.

22. Norman DA, Shallice T. Attention to action: willed and automatic control of behavior. U: Davidson RJ, Schwartz GE, Shapiro D, ur. Consciousness and self regulation: advances in research. New York: Plenum Press; 1986. 1-18.

23. Posner MI, Petersen SE. The attention system of the human brain. Annu Rev Neurosci. 1990; 13: 25-42.

24. Baddeley AD. Working memory. Oxford: Oxford University Press; 1986.

25. Burgess PW, Alderman N, Forbes C, Costello A, Coates LM, Dawson DR, et al. The case for the development and use of „ecologically valid” measures of executive function in experimental and clinical neuropsychology. J Int Neuropsychol Soc. 2006; 12(2): 194-209.

26. Šimleša S. Izvršne funkcije i teorija uma kod osoba s poremećajem iz autističnoga spektra. Psihologijske teme. 2011; 20(1): 91-114.

27. Heaton RK, Chelune GJ, Talley JL, et al. Wisconsin Card Sorting Test manual. Odessa: Psychological Assessment Resources; 1993.

28. Marvel CL, Desmond JE. The contributions of cerebrocerebellar circuitry to executive verbal working memory. Cortex. 2010; 46(7): 880-895.

29. Manchester D, Priestley N, Jackson H. The assessment of executive functions: coming out of the office. Brain Inj. 2004; 18(11): 1067-1081.

30. Wilcock AA. An Occupational Perspective of Health. 2. izd. Thorofare, NJ: Slack Incorporated; 2006.

31. Allen CK, Earhart CA, Blue T. Allen Cognitive Level documentation. Colchester, CT: S\&S/Worldwide; 1996.

32. Fisher AG. The assessment of IADL motor skills: An application of many-faceted Rasch analysis. Am J Occup Ther. 1993; 47(4): 319-329.

33. Burgess PW, Alderman N, Emslie H, Evans JJ, Wilson BA. Behavioural Assessment of the Dysexecutive Syndrome: The dysexecutive questionnaire. Bury St. Edmund, UK: Thames Valley Test Company; 1996.

34. Baum CM, Connor LT, Morrison T, Hahn M, Dromerick AW, Edwards DF. Reliability, validity, and clinical utility of the 
Executive Function Performance Test: A measure of executive function in a sample of people with stroke. Am J Occup Ther. 2008; 62(4): 446-455.

35. Baum CM, Edwards DF. Cognitive performance in senile dementia of the Alzheimer's type: The kitchen task assessment. Am J Occup Ther. 1993; 47: 431-436.

36. Goverover Y, Kalmar J, Gaudino-Goering E, Shawaryn M, Moore NB, Halper J, et al. The relation between subjective and objective measures of everyday life activities in persons with multiple sclerosis. Arch Phys Med Rehabil. 2005; 86(12): 2303-2308.

37. Baum CM, Morrison T, Hahn M, Edwards DF. Test manual: Executive Function Performance Test. St. Louis, MO: Washington University; 2003.

38. Baum CM, Morrison T, Hahn M, Edwards DF. Executive Function Performance Test: Test Protocol Booklet; Program in Occupational Therapy. St. Louis, MO: Washington University; 2007.

39. Guide for the Uniform Data Set for Medical Rehabilitation (including the FIM(TM) instrument). Version 5.1. Buffalo, NY: University of New York; 1997.

40. Donaghy S, Wass PJ. Interrater reliability of the functional assessment measure in a brain injury rehabilitation program. Arch Phys Med Rehabil. 1998; 79(10): 1231-1236.

41. Wolf TJ, Stift S, Connor LT, Baum C, The Cognitive Rehabilitation Research Group. Feasibility of using the EFPT to detect executive function deficits at the acute stage of stroke. Work. 2010; 36(4): 405-412.
42. Goverover Y, Chiaravalloti N, Gaudino-Goering E, Moore N, DeLuca J. The relationship among performance of instrumental activities of daily living, self-report of quality of life, and self-awareness of functional status in individuals with multiple sclerosis. Rehabil Psychol. 2009; 54(1): 60-68.

43. Katz N, Tadmore I, Felzen B, Hartman-Maeir A. Validity of the Executive Function Performance Test in Individuals with Schizophrenia. OTJR-Occup Part Heal. 2007; 27(2): 1-8.

44. Kato A, Hashiba T, Hashimoto N, Izumoto S, Suzuki T, Kagawa N, et al. Serial volumetric assessment of the natural history and growth pattern of incidentally discovered meningiomas. J Neurosurg. 2009; 110(4): 675-684.

45. The Brain Tumour Charity. Personality Changes and Brain Tumours [internet]. Hampshire: The Brain Tumour Charity; 2016. Dostupno na: https://www.thebraintumourcharity.org/understanding-brain-tumours/livingwith-a-brain-tumour/side-effects/personality-changesand-brain-tumours/ (pristupljeno 5.6.2017.).

46. Cahn-Weiner DA, Boyle PA, Malloy PF. Tests of executive function predict instrumental activities of daily living in community-dwelling older individuals. Appl Neuropsychol. 2002; 9(3): 187-191.

47. Chaytor N, Schmitter-Edgecombe M, Burr R. Improving the ecological validity of executive functioning assessment. Arch Clin Neuropsychol. 2006; 21(3): 217-227.

48. Law MC, Baptiste S, Carswell A, McColl MA, Polatajko HJ, Pollock N. Canadian Occupational Performance Measure. 4. izd. Ottawa, ON: CAOT Publications ACE; 2005. 


\section{APPLICATION OF THE EXECUTIVE FUNCTION PERFORMANCE TEST (EFPT) AFTER MENINGIOMA SURGERY}

Matea Ćelić

1 Andreja Bartolac

${ }^{1}$ University of Applied Health Sciences Zagreb on-oriented rehabilitation, and considering the lack of such assessment instruments in practice, the EFPT is potentially a very useful tool for assessing the degree of independence in performing everyday activities. Moreover, we suggested solutions to aforementioned methodological challenges in applying this test.

\begin{abstract}

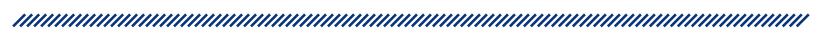

Executive functions are an integrating system of interconnected central neural processes that regulate higher-order cognitive functions and allow us to understand human behaviour. Executive function disorder is reflected through difficulties in performing everyday activities in an independent and purposeful way. The aim of this paper is to analyse the occupational performance of a person with an executive function disorder through an assessment that is not based on isolated features of executive functions, but on the integration of these features based on the task being performed. In accordance with the occupational paradigm in which a link between occupation and health exists, we applied the Executive Function Performance Test (EFPT) and performed a case study of a female client after frontal meningioma surgery. Although the test satisfied the psychometric properties, at certain points the items were not adjusted to the Croatian context, since descriptions of tasks allowed only one way of their execution, which were its main downside. Also, the standardized guidance system in the test may not reflect the actually needed level of assistance, since the test equipment was not sorted according to the real context. Nevertheless, from a perspective of the occupati-
Keywords: executive functions, occupational assessment, case study 